\title{
Development of Water Quality Modeling in the United States
}

\author{
Robert B. Ambrose, Jr. ${ }^{\dagger}$, Tim A. Wool ${ }^{1}$, and Thomas O. Barnwell, Jr. \\ U.S. Environmental Protection Agency (retired) \\ ${ }^{1}$ U.S. Environmental Protection Agency, Region 4 Water Management Division
}

Received November, 2009; Accepted November, 2009

\begin{abstract}
The modern era of water quality modeling in the United States began in the 1960s. Pushed by advances in computer technology as well as environmental sciences, water quality modeling evolved through five broad periods: (1) initial model development with mainframe computers (1960s - mid 1970s), (2) model refinement and generalization with minicomputers (mid 1970s - mid 1980s), (3) model standardization and support with microcomputers (mid 1980s - mid 1990s), (4) better model access and performance with faster desktop computers running Windows and local area networks linked to the Internet (mid 1990s - early 2000s), and (5) model integration and widespread use of the Internet (early 2000s - present). Improved computer technology continues to drive improvements in water quality models, including more detailed environmental analysis (spatially and temporally), better user interfaces and geographic information system software, more accessibility to environmental data from on-line repositories, and more robust modeling frameworks linking hydrodynamics, water quality, watershed and atmospheric models. Driven by regulatory needs and advancing technology, water quality modeling will continue to improve to better address more complicated water bodies and pollutant types, and more complicated management questions. This manuscript describes historical trends in water quality model development in the United States, reviews current efforts, and projects promising future directions.
\end{abstract}

Keywords : Water quality models, Computing trends, Model development, Model integration

\section{Introduction}

Water quality modeling has a relatively long history in the United States. While its origins lie in the work of Streeter and Phelps in the 1920s, ${ }^{1)}$ the practice began its first modern development phase with the availability of mainframe computers in the 1960s. Successive development phases have been driven by the availability of desktop computers in the late 1980s, improved Windows operating systems in the mid to late 1990s, and the internet in the later 1990s to the present.

Model development has also been driven by the needs of regulation. The primary regulatory driver for water quality modeling in the U.S. has been the 1956 Federal Water Pollution Control Act, including the Clean Water Act and amendments of 1972, 1977, 1981, and 1987. Four U.S. laws address the environmental risks from toxic substances and their effect on watersheds. These regulate industrial chemicals (Toxic Substances Control Act), contaminated sites (Superfund), hazardous waste (Resource Conservation and Recovery Act), and pesticides (Federal Insecticide, Fungicide, and Rodenticide Act).

A variety of institutions in the United States have promoted the development of water quality models. This has been the product of a broad collaboration, both cooperative and adversarial, between government, academia, and private firms (industry and engineering consultants). While the U.S. Environmental Protection Agency (EPA) has been a leader in the broad development and use of water quality models, other federal and state agencies have made strong contributions to the field. Chief among these are the U.S. Army Corps of Engineers' Hydrologic Engineering Center (HEC) and Waterways Experiment Station, which have been longstanding leaders in hydrologic and water quality modeling. Other major contributors include the Tennessee Valley Authority, the National Oceanic and Atmospheric Administration, the U.S. Department of Agriculture, the U.S. Geologic Survey (USGS), and the U.S. Department of Energy at its Battelle Pacific Northwest Laboratories.

Water quality model development has also been driven incrementally by the underlying process science. Most of the conventional water quality variables and processes ${ }^{2)}$ were coded in modeling frameworks by the late 1970s, and toxicant variables and processes were coded by the mid-1980s. ${ }^{3)}$ Since then, water quality modeling content has been slowly refined and improved

${ }^{\dagger}$ Corresponding author

E-mail: rambrose@alum.mit.edu

Tel: +01-706-296-5228, Fax: (no fax) 
in a variety of applications. Present high-end water quality models feature multiple algal groups and detrital variables, and linkages to sediment diagenesis modules.

The basic steps in water quality modeling applications were established by the early 1970 s. The two primary elements were model calibration and verification, a step that is now generally known as validation. These two steps were generally followed by sensitivity analysis and then scenario analysis. In the calibration step, input coefficients were adjusted to give a qualitatively best fit to an observed data set. In the verification step, the calibrated model was applied to one or more independent data sets, adjusting forcing functions as appropriate but without adjusting calibrated coefficients. In the sensitivity analysis step, model coefficients and forcing functions were adjusted through fixed percentages or ranges, and resulting changes in model output were quantified. The knowledge gained in this step was sometimes used to fine-tune the model. Finally, the model was used to predict the water quality outcome of possible management scenarios.

\section{Historic Trends}

It is convenient to divide modern American water quality modeling into five periods characterized by the available computer technology:

- 1960s to mid-1970s: mainframe computers

- Late-1970s - mid-1980s: minicomputers

- Mid-1980s - mid-1990s: microcomputers (DOS)

- Late-1990s - mid-2000s: microcomputers (Windows); Internet

- Late-2000s: Internet with remote-access databases

Of course these periods are not discrete, and technology such as mainframe and minicomputers continue to be used to the present.

\section{1. $1960 \mathrm{~s}$ to mid-1970s}

The first modern development phase of water quality models began with the availability of mainframe computers in the 1960s. Computers were typically accessed remotely through punch card input. Model code and input data were submitted to a queue. The batch job usually involved compiling and linking the model, running the input dataset, and then routing output to a remote printer. Model output could be stored on magnetic tape and accessed by future runs. Simulation "turn-around" times could be as little as minutes during off-peak times to as long as hours during the work day. The relative computational expense limited most studies to simplified spatial or temporal domains. While simplified box models could simulate eutrophication dynamics in lakes using large time steps over several years, more complex spatial models of rivers or estuaries typically employed steady state or stationary (dynamic steady state) simulations of critical conditions.

During this early period, a variety of water quality models were developed. Some of the most prominent included:

\footnotetext{
- Early water quality analysis stimulation program(WASP) box models

- Dynamic estuary model (DEM)

- Storm water management model (SWMM)

- Early QUAL models

- MIT dynamic network model (MIT-DNM)

- Stanford watershed model
}

The early Manhattan College WASP models were used to investigate nutrient-eutrophication dynamics in the Sacramento River, ${ }^{4)}$ the Great Lakes, ${ }^{5-7)}$ and dissolved oxygen in the Delaware Estuary. ${ }^{8,9)}$ The $\mathrm{DEM}^{10)}$ was used to simulate stationary, tidally driven dissolved oxygen and nutrient-phytoplankton dynamics in San Francisco-San Joaquin Delta, the Potomac Estuary, and the Delaware Estuary. SWMM ${ }^{11,12)}$ was used to simulate urban storm water hydrology and pollutant runoff loading for many cities in the U.S. It is the primary tool for large municipalities to develop storm water master plans (New York, Chicago, Atlanta and many more). The early QUAL models were used for steady-state dissolved oxygen studies in streams. ${ }^{13-15)}$ The MIT-DNM ${ }^{16)}$ was a finite element model used to simulate nitrogen-phytoplankton dynamics in estuaries. The Stanford watershed model ${ }^{17)}$ was a box model developed to simulate surface hydrology, including runoff and infiltration from a multi-year rainfall record. Each of these models became the basis for continuing model development and application efforts during and beyond this initial period.

\subsection{Late 1970 s to mid-1980s}

The second modern development phase of water quality models began with the availability of minicomputers in the mid 1970s. Because the minicomputers were owned and operated at the government or research institution and connected to a local network of terminals, access was much improved. Model code could be compiled and stored as executable, and simulations were run batch using text file input consisting of a sequence of card images. Individual runs were cheaper and quicker, promoting more calibration and sensitivity runs.

During this period, older models were refined and generalized. Government modeling centers arose and, teamed with academic and consulting partners, actively pursued model development and application. In addition, private and academic centers of expertise independently pursued model development in the context of large regulatory applications. New models were developed for different problems, such as organic toxicants and metals. Some noteworthy model development programs included:

- U.S. EPA, Center for Water Quality Modeling (CWQM), Athens, GA - Hydrologic simulation program - Fortran (HSPF)

○ WASP3

$\circ$ QUAL2E

○ Exposure analysis modeling system (EXAMS)

- U.S. Army Corps of Engineers, Waterways Experiment Station, Vicksburg, MS

○ CE-QUAL-R1

- CE-QUAL-W2

○ CE-QUAL-RIV1

- U.S. Army Corps of Engineers, HEC, Davis, CA

○ HEC-RAS

$\circ$ HEC-DSS

$\circ$ HEC-HMS

HSPF was developed using structured programming techniques. ${ }^{18)}$ Although the code was completely new, its algorithms were derived from the hydrologic simulation program, which was based on the Stanford watershed model, along with the agricultural runoff model and nonpoint source model. HSPF is a comprehensive watershed model that simulates nutrient and pesticide transport and fate in land and water segments. Following several WASP applications by Manhattan College, the basic WASP modeling framework was delivered to EPA. ${ }^{19)}$ Ambrose 
et al. ${ }^{20)}$ developed WASP3 for large rivers, lakes, and estuaries by linking the basic framework with hydrodynamic, eutrophication, and toxic chemical modules. The QUAL2E steady-state stream model was developed from QUAL-Tex and other versions by adding appropriate algorithms, thoroughly reviewing code, and developing an external uncertainty and sensitivity analysis driver. ${ }^{21)}$ The exposure analysis modeling system, EXAMS, is a compartment model of surface water pesticide fate developed by combining state-of-the-art chemical process algorithms with simple loading and transport algorithms. ${ }^{22,23)}$ Though the model is general, it has been applied primarily to farm ponds and simple stream reaches.

The U.S. Army Corps of Engineers Waterways Experiment Station (now known as the Engineer Research and Development Center) developed a series of hydrodynamic and water quality models to be used to manage reservoirs. The first dynamic model was CE-QUAL-R1, a one-dimensional (vertical) hydrodynamic and water quality model developed to manage water quality in reservoirs. Its predecessor, CE-QUAL-W2 is a two-dimensional (longitudinal and vertical) hydrodynamic and water quality model for simulating water quality in reservoirs. This is the most widely applied hydrodynamic and water quality model for reservoirs in the U.S. It has also been applied to some estuaries. The HEC has also developed a series of hydraulic and water quality models that are used throughout the U.S. The most notable tool is HEC-RAS (riverine analysis system). HEC-RAS supports one-dimensional steady flow, unsteady flow, sediment transport/mobile bed computations, and water temperature modeling.

\subsection{Mid-1980s to mid-1990s}

The third modern development phase of water quality models began with the availability of microcomputers in the mid 1980s. Because the microcomputers were located in the user's office, access was again significantly improved. Model executables and supporting databases were installed locally. Most simulations were run batch using text file input along with ad hoc databases containing, for example, meteorological or flow data. Desktop technology promoted more hands-on calibration and sensitivity analysis, but there were definite limitations in speed and storage capacity. High-end simulation with large networks was still conducted remotely on mainframes or minicomputers.

During this period, older models were further refined and generalized. Models became more standardized, with formal distribution, training courses, and technical support for the general user. The U.S. EPA CWQM became the Center for Exposure Assessment Modeling (CEAM), and expanded the range of models developed and supported. WASP versions 4 and 5 were issued with updated water quality modules and better transport linkages, and initial versions of pre- and post-processors were developed. ${ }^{24)}$ QUAL2E-UNCAS was refined by Brown and Barnwell ${ }^{25)}$ and widely applied by Barnwell et al. ${ }^{26)}$ HSPF was further developed and applied by expert consultants to watersheds around the country. EXAMS was linked with pesticide root zone model (PRZM), a field-scale pesticide fate model, and used to screen new pesticide registration. The metals speciation model MINTEQ was further developed and applied in some water bodies to complement more traditional chemical fate modeling.

On the high end, multidimensional hydrodynamic models became more practical, and were linked internally or externally with water quality and watershed models. One prominent example is the U.S. ACE modeling of Chesapeake Bay using a three-dimensional hydrodynamic model $\mathrm{CH}_{3} \mathrm{D}^{27)}$ linked with the water quality model CE-QUAL-ICM ${ }^{28)}$ and the watershed model HSPF. Another significant upper-end model developed during this period is the environmental fluid dynamics mode (EFDC ${ }^{29)}$ which is an enhancement of the Princeton ocean model (POM $)^{30}$ EFDC is an orthogonal, curvilinear grid hydrodynamic model that can be used to simulate aquatic systems in one, two, and three dimensions. EFDC simulates the circulation and transport of material in complex surface water environments including estuaries, coastal embayments, lakes, and offshore.

\subsection{Late 1990 s to mid-2000s}

The fourth modern development phase of water quality models began with improvements to the Windows operating system in the mid 1990s, along with higher-capacity local area networks linked to the Internet, and faster desktop computers. This technology brought desktop access to remote data and information sources. Standardized desktop database and spreadsheet software enabled more thorough analysis of observed data and model output. Model graphical user interfaces (GUIs), including preprocessors, graphical postprocessors and geographic information system (GIS) linkages, greatly facilitated access to the models and expanded their reach. Model distribution over the Internet became commonplace, increasing access worldwide. Specialized model frameworks improved, facilitating linkage of models to each other and to relevant databases. In some laboratories and universities, local computer networking clusters facilitated MonteCarlo simulations, improving sensitivity and uncertainty analysis for high-end applications.

SWMM continues to be widely used throughout the world for planning, analysis and design related to storm water runoff, combined sewers, sanitary sewers, and other drainage systems in urban areas, with many applications in non-urban areas as well. The current edition, Version $5{ }^{31)}$ is a complete re-write of the previous release. Running under Windows, SWMM 5 provides an integrated environment for editing study area input data, running hydrologic, hydraulic and water quality simulations, and viewing the results in a variety of formats. These include color-coded drainage area and conveyance system maps, time series graphs and tables, profile plots, and statistical frequency analyses.

During this period, the U.S. EPA Office of Water sponsored the development of better assessment science integrating point and nonpoint sources (BASINS), a multipurpose environmental analysis system designed for performing watershed and water quality-based approaches to watershed management and environmental protection. The BASINS framework integrates GIS technology, environmental databases, analytical tools, and modeling programs to support development of cost-effective watershed management plans, including total maximum daily loads (TMDLs). The initial version, issued in 1996, was based on ArcView2. Subsequent versions 2.0 (1998), 3.0 (2001), and 3.1 (2004) operated with ArcView3.x. HSPF is the key watershed model linked with BASINS.

U.S. EPA Office of Water also sponsored development of QUAL2K, ${ }^{32)}$ a Windows-based update version of QUAL2E with improvements in model segmentation, forms of carbonaceous biochemical oxygen demand (BOD) evaluated, particulate organic matter simulation, anoxia and denitrification modeling, sedimentwater dissolved oxygen and nutrient fluxes, explicit simulation of attached bottom algae, light extinction calculation, enhanced $\mathrm{pH}$ simulation, and pathogen removal functions.

U.S. EPA Region 4 developed efficient hydrodynamic linkage routines for the WASP model. This allowed the linkage of three- 
dimensional hydrodynamic models like EFDC to WASP both in time and space. This greatly improved the use of large-scale hydrodynamic models in water quality model applications. U.S. EPA Region 4 applied this methodology to several estuaries in the Southeast. ${ }^{33)}$

\section{Current Efforts}

The latest modern development phase of water quality models began with improvements and widespread use of the Internet in the early to mid 2000s. Improved computer technology continues to drive and enable expansions and improvements in water quality models. This includes faster computers capable of handling more detailed environmental analysis (spatially and temporally), better user interfaces and GIS software, more accessibility to environmental data from on-line repositories, and more robust modeling frameworks linking hydrodynamics, water quality, watershed and atmospheric models. An example of the impact of faster computers is the use of dynamic, spatially detailed simulations driven by better transport models such as EFDC, the environmental fluid dynamics code. ${ }^{29)}$ The use of this three-dimensional transport model to simulate water movement in complex systems has been instrumental in improving the prediction capabilities of water quality models such as WASP. ${ }^{33}$ This model is also being applied to the Han River and Yongdam Lake in Korea. ${ }^{34-36)}$

Presently available computers also support the development of GUIs, including GIS linkages and interfaces. Specialized user interface software has promoted better water quality modeling practice. One example is the WASP Windows interface and its graphical postprocessor. Improved user interfaces with linkages to geographical information and water quality monitoring data now help the model practioner set up and calibrate models more rapidly than in the past. User interfaces help alleviate data transcription errors introduced into model runs through editing of formatted or unformatted model input files. Advancements in graphical post processors enable model practioners and stakeholder groups to better understand the performance and capability of the model. The ability to animate predicted water quality dynamics on a geographical map gives model users, stakeholders, and decision makers the ability to quickly focus on critical areas and make better decisions on management of the water resource.

Detailed geographical information is now readily available for most watersheds in the U.S. The USGS provides access to the National Hydrography Dataset (NHDPlus), which provides detailed information about all river, streams, lakes and reservoirs. For each stream segment, these details include channel geometry (length, width, depth, average flow, slope), connectivity with other channels, and cumulative drainage area. NHD supports watershed delineation into catchments that can be used in the application of watershed models. These catchments include the 2002 land use classification. The NHDPlus dataset also includes digital elevation coverage of the area of interest. This allows the model practioner to visualize the landscape and changes in topography. The USGS also provides access to its extensive monitoring network for flow and water quality. Time series data for flows and water quality can be obtained from the USGS webpage. Users can download data from many of the USGS real-time gages, which include flows for the period of record through the day before download. The US EPA allows the download of ambient water quality data from its STORET system, which is populated with data provided by the states. This readily accessible database allows the model practioner to process and utilize water quality data in the setup and parameterization of models.

Several robust frameworks facilitate the linkage of external data sources, databases and simulation models, promoting more comprehensive analyses of environmental problems. These frameworks allow the linkage of a series of models representing constituent transport and transformation through different environmental media, including atmosphere, watershed, groundwater, surface water, and aquatic communities. These models may include stand-alone "legacy" models as well as specialty modules developed specifically for use in the framework. Often separate hydrologic and hydrodynamic models are linked to their biogeochemical and water quality counterparts in soil and surface water media. The BASINS framework, sponsored and supported by U.S. EPA Office of Water, is being used in the US for watershed and water quality modeling. This framework is summarized below and in the Appendix.

BASINS is a geographical information system that has the ability to download, process and display environmental data that is used in watershed assessments and model applications. BASINS utilizes MapWindow, an open source geographical information system, to process the geographical information. This program is free of charge and provides much of the needed GIS processing capabilities. BASINS has the ability to aid the user in setting up watershed models (i.e. HSPF, SWAT, SWMM, PLOAD, GWLF), surface water models (i.e. WASP), and ecological response models (i.e. AQUATOX). BASINS provides tools for downloading geographical information and time series data from external data sources (USGS and U.S. EPA). BASINS also provides a series of generalized library functions for transferring the output from one model to the input for another model. BASINS includes plug in capabilities for a series of tools that can be used to characterize a watershed (inventory, land uses, point sources, population, soils type, etc.) and to build sophisticated databases of the downloaded time series data.

\section{Future Directions}

Driven by regulatory needs and advancing technology, water quality modeling in the U.S. should continue to improve on several fronts. The TMDL program will be addressing more complicated water bodies and pollutant types, and addressing more complicated management questions. In particular, models will be used for aiding in large-scale management decisions that could have significant costs associated with the implementation of the appropriate controls. Some implications for model development are discussed below. Many of the trends are significantly under way.

Managing nutrients over regional scales, such as the Mississippi River Basin, will require models capable of addressing large spatial and long temporal domains. Furthermore, questions about the impact of broad policies, such as the promotion of biofuels, will require the linkage of economic production models with watershed, ground water, and surface water models. These models will need to be integrated within more capable frameworks allowing efficient transfer of predictions, including feedback. For efficiency, modeling frameworks will be enhanced to automatically connect models to external data. Present capabilities in linking to online databases will evolve to include real time data for meteorology, flows, and point source discharges. 
The need for larger model domains and longer simulation periods will drive improvements in model solution efficiencies and the development of techniques to take advantage of new computer technology. Parallel processing algorithms will be incorporated into models to better utilize personal computers with multiple central processing units, allowing different sections of a model to be solved simultaneously. The use of distributive processing will increasingly take advantage of the Internet and supercomputer technology. Model simulations will be performed on a super computer away from the modeler's personal computer, which will be used to parameterize the model (input) and review model output (post process).

In order to better digest output from multiple models over large domains and time periods, visualization software will be standardized and improved. This will allow modelers and decision makers to better understand the model predictions for alternate scenarios.

A key aspect of modeling that is receiving increasing attention is the process of model development and application. Models are critical to regulatory decision making because the spatial and temporal scales linking environmental controls and environmental quality often do not allow for an observational approach to understand the relationship between pollutant sources, much less economic activity, and environmental quality. ${ }^{37)}$ Models have a long history of helping to explain scientific phenomena and predicting outcomes and behavior in settings where empirical observations are limited or unavailable.

The U.S. EPA uses a wide range of models to inform decisions that support its mission, ranging from simple to complex and many employ a combination of scientific, economic, socioeconomic and other data. As models become increasingly significant in decision-making, it is important that the model development and application process conforms to standards that ensure the usability, soundness, and defensibility of their outputs for decision making. Hence, the agency recently published the guidance on the development, evaluation, and application of environmental models. ${ }^{38)}$ The guidance presents recommendations drawn from a wide range of sources that are generally applicable to all models regardless of domain, mode, conceptual basis, form, or level of rigor. It provides and overview of best practices for ensuring the quality of environmental models. The primary purpose of the guidance is to provide specific advice on how to perform model quality checks during model development, evaluation and application. Following the best practices outlined in the guidance, together with well-documented QA project plans, will ensure the results of modeling projects and the decisions informed by tem meet the Agency's needs.

\section{Appendix - Summary of Key U.S. EPA Models}

\subsection{BASINS4}

The watershed modeling framework most used in the U.S. is BASINS. For information about BASINS, visit basins@epa.gov, the BASINS web site at http://www.epa.gov/waterscience/basins, and/or join the Listserver at http://www.epa.gov/waterscience/ basins/listserv.htm.

BASINS is a multipurpose environmental analysis system designed for use by regional, state, and local agencies in performing watershed and water quality-based studies. This system makes it possible to quickly assess large amounts of point and non-point source data in a format that is easy to use and understand. BASINS allows the user to assess water quality at selected stream sites or throughout an entire watershed. This framework integrates environmental data, site properties, analytical tools, and pollutant source and transport and fate simulation modeling to support development of cost-effective approaches for watershed management and environmental protection, including development of TMDLs.

BASINS was developed using ArcView. Version 1.0 was released in May 1996 with ArcView 2.x, and subsequent releases through Version 3.1 in August 2004 utilized later ArcView releases. Work then began using the open source MAPWindow GIS, and in April 2007, BASINS 4 was released.

BASINS4 includes GIS tools in the front-end (data download tool, watershed delineation, watershed characterization reports, and weather data manager utility [WDMUtil] for time-series). The delineation of a watershed with the GIS creates sub-basin boundaries, stream networks, and input/output locations for the water quality models. BASINS 4.0 Release 1 includes HSPF and PLOAD watershed pollutant loading models, and a link to the AQUATOX aquatic ecosystem model. ${ }^{39)}$ Later releases include the USDA's watershed runoff model SWAT and the surface water body model WASP.

BASINS4 is based on Mapwindow, an open source "programmable GIS" that supports manipulation, analysis, and viewing of geo-spatial data and associated attribute data in several standard GIS data formats. Mapwindow is both a mapping tool and a GIS application programming interface in one convenient, re-distributable, open source solution. Using these open source GIS tools and non-proprietary, standard data formats to accommodate users of several different GIS software platforms, BASINS4 becomes independent of any proprietary GIS platform and available for useful "plug-ins."

\subsection{WASP}

The water quality analysis simulation program, WASP $\mathrm{P}^{19,24,40)}$ is a general dynamic mass balance framework for modeling contaminant fate and transport in surface waters. Based on the flexible compartment modeling approach, WASP can be applied in one, two, or three dimensions with advective and dispersive transport between discrete physical compartments, or "segments." WASP provides a selection of modules to allow the simulation of conventional water quality variables as well as toxicants.

The toxicant WASP modules combine a kinetic structure initially adapted from EXAMS ${ }^{22)}$ with the WASP transport structure and simple sediment balance algorithms to predict dissolved and sorbed chemical concentrations in the water and underlying sediment bed ${ }^{41)}$ The standard eutrophication WASP module combines a kinetic structure initially adapted from the Potomac eutrophication model ${ }^{42)}$ with the WASP transport structure to predict nutrients, phytoplankton, periphyton, organic matter, and dissolved oxygen dynamics. ${ }^{20)}$ Later enhancements include the addition of benthic algae ${ }^{43)}$ and multiple phytoplankton classes. Transport options include internal stream transport algorithms and external linkage to EFDC and DYNHYD. ${ }^{44}$

During the 1990s, a Windows-based interface for constructing input datasets and managing simulations was developed and implemented, culminating in WASP6. ${ }^{40)}$ Data can be copied and pasted from spreadsheets. A Windows-based post-processor allows the user to plot or animate model output. Output is also provided as comma-delimited files for import to spreadsheets. 
Water quality modules in WASP7 include heat, standard eutrophication, advanced eutrophication, simple toxicants, nonionizing toxicants, organic toxicants, and mercury.

WASP has a long history of application to a variety of water bodies for a variety of water quality problems. Earlier versions of WASP were used to examine eutrophication and PCB pollution of the Great Lakes, ${ }^{5-7,45)}$ eutrophication of the Potomac Estuary, ${ }^{42)}$ kepone pollution of the James River Estuary, ${ }^{46)}$ heavy metal pollution of the Deep River, North Carolina, ${ }^{47)}$ and volatile organic pollution of the Delaware River Estuary. ${ }^{48)}$ In addition to these, numerous applications are listed in Di Toro et al. ${ }^{19)}$

Published applications of more recent versions of WASP include eutrophication and mixing in Prince William Sound embayments, ${ }^{49)}$ eutrophication in the inner shelf of the Gulf of Mexico, ${ }^{50)}$ eutrophication in the Mississippi River and Lake Pepin, ${ }^{51)}$ water quality of the Speed River, ${ }^{52,53)}$ metam spill in the Sacramento River, ${ }^{54)}$ pollutant loading for the Black and Chehalis Rivers in Washington, ${ }^{55)}$ mercury in the Everglades ${ }^{56)}$ and in small rural catchments, ${ }^{57)}$ hydrodynamics and water quality in a large South Carolina reservoir, ${ }^{58,59)}$ eutrophication of Tampa Bay, ${ }^{60)}$ eutrophication in the Neuse River Estuary, ${ }^{33)}$ metals in Upper Tenmile Creek, Montana, ${ }^{61-63)}$ and mercury in a South Georgia (USA) river basin. ${ }^{64)}$

\subsection{QUAL}

The QUAL series of one-dimensional steady state stream models have a long history in water quality modeling. The Texas Water Development Board (TWDB) laid the foundation upon which the series is built in the late 1960s. The original model, QUAL I, ${ }^{13)}$ was used as a tool to evaluate flow augmentation for temperature and dissolved oxygen control. In the early 1970s, the U.S. EPA Office of Water began a program to provide water quality models for major river basins and specified that QUAL I be used as the basis for developing new, more advanced, basin specific models. Many versions of the QUAL II model emerged from this effort. One in particular included a special solution algorithm for the steady state condition. ${ }^{14)}$ This version was further improved in the mid 1970s for the Southeast Michigan Council of Governments (SEMCOG), the area-wide wastewater-planning agency for the Detroit metropolitan area. Because of its flexibility and thorough documentation, this version of QUAL II, known as QUAL II/ SEMCOG, ${ }^{15)}$ was chosen for distribution by the U.S. EPA's CWQM and received widespread use, especially in waste load allocation studies.

Because mathematical water quality models were being used to determine effluent limits for a number of paper industry discharges, the National Council of the Paper Industry for Air and Stream Improvement (NCPIASI) undertook a thorough review, testing and documentation project covering a variety of water quality models, including QUAL II/SEMCOG ${ }^{65)}$ Changes resulting from this review were incorporated in the EPA distributed program and the model was renamed QUAL II/NCASI.

NCPIASI and other groups such as the USGS tested the revised program on several intensively sampled rivers across the U.S. An objective comparison of QUAL II/NCASI with other computer codes (SNSIM, DOSAG, and QUAL I) on the Ouachita River in the southeastern United States ranked QUAL II as the model with the best predictive ability. ${ }^{66,67)}$ ranked QUAL II/NCASI as the best steady state model among several compared on the Chattahoochee River (southeastern United States), the Willamette River (northwestern U.S.), and the Arkansas River (western U.S.).

Testing of QUAL II/NCASI on the Ouachita River identified some difficulties in the steady state algal simulation routines. To match observed data, it was necessary to adjust input parameters to the extremes of their expected ranges. As a result, EPA and NCPIASI began a joint project to resolve these problems. During the joint project, NCPIASI ${ }^{68)}$ reviewed other versions of the QUAL II model that included modifications for conditions found in the states of Vermont, Texas, and Wisconsin. A number of common modifications and extensions were discovered in the review and subsequently were incorporated into an enhanced version of the model called QUAL2E. ${ }^{21)}$ These changes included such kinetic processes as nitrification suppression at low dissolved oxygen levels, additional algal growth, kinetic, and light response options, and the inclusion of algal self-shading. Further testing using the Ouachita data set revealed the value of the addition of detailed hydraulic output that prints many internally calculated values such as stream width, depth, and velocity. This testing also confirmed the importance of the algal self shading process in lending accuracy and stability to model simulations.

QUAL2K is an independently developed version of QUAL that is implemented within Excel. ${ }^{69,70)}$ This model handles branching one-dimensional, steady flow stream and river systems with diurnal kinetics. Significant features of QUAL2K include:

- Unequally-spaced reaches with multiple loadings

- Carbon: slowly oxidizing CBOD, rapidly oxidizing CBOD, and nonliving particulate organic matter (detritus)

- Nutrients: nitrogen and phosphorus cycles

- DO and anoxia simulation: reduced oxidation reactions at low DO

- Sediment-water interactions: DO and nutrient fluxes simulated

- Algae: phytoplankton and attached bottom algae simulated

- Light extinction: a function of algae, detritus and solids

- pH: Both alkalinity and total inorganic carbon are simulated

- Pathogens: removal a function of temperature, light, and settling.

\section{4. HSPF}

The hydrologic simulation program - Fortran, HSPF, is a comprehensive watershed model that simulates watershed hydrology as well as nutrient and pesticide transport and fate in land and water segments. HSPF was developed using structured programming techniques. Although the code was completely new, its algorithms were derived from the hydrologic simulation program based on the Stanford watershed model, ${ }^{17}$ along with the agricultural runoff management model, $\mathrm{ARM}^{71,72)}$ and the nonpoint source loading model, NPS ${ }^{73)}$ The initial public release of HSPF was version 5, with an enhanced version 6 following in 1980 and version 7 in $1981 .{ }^{74)}$ Version 8 for PCs followed in $1984 .{ }^{18,75)}$ Release 9 in 1988 implemented the watershed data management (WDM) system and was supported and distributed by CEAM. Version $10^{76)}$ included sediment-nutrient interactions and an acid-pH module. Version $11^{77)}$ included process enhancements and a forest nitrogen module. Version $12^{78)}$ includes wetland and shallow water tables, irrigation, simplified snow algorithms, a box model of flow and sediment and BMP report modules.

HSPF incorporates watershed-scale models into a basinscale analysis framework that includes pollutant transport and fate in one dimensional stream channels. HSPF uses continuous rainfall and other meteorological records to compute stream flow hydrographs and pollutographs. HSPF is organized into three primary modules for simulating the main features of a watershed. PERLND simulates the water quality and quantity processes that occur on a pervious land segment. A land segment is a subdivision of the simulated watershed defined as an area 
with similar hydrologic characteristics. A segment of land that has the capacity to allow enough infiltration to influence the water budget is considered pervious. IMPLND simulates water quantity and quality accumulation and runoff from impervious land segments. In a connected impervious land segment, little or no infiltration occurs. Snow accumulation and melting is simulated as is water storage, evaporation and export. Various water quality constituents are loaded, accumulated and/or removed. Water, solids, and various associated pollutants flow from the segments by moving laterally to a down slope segment or to a stream or lake. The RCHRES module simulates the pollutant transport and fate processes that occur in each reach of open or closed receiving stream channel or in a completely mixed lake.

HSPF has a long history of application to a variety of watersheds for hydrologic response and nutrient and pesticide runoff. Many citations are available at http://www.aquaterra. com/resources/hspfsupport/hspfbib.php. Notable applications include the study of agricultural best management practices in Four Mile Creek, Iowa ${ }^{79)}$ and in the Iowa River Basin, ${ }^{80,81)}$ hydrologic simulation of Tennessee's North Reelfoot Creek, ${ }^{82)}$ rainfall-runoff for headwater basins in Western King and Snohomish Counties, Washington, ${ }^{83)}$ nutrient loadings to the Chesapeake Bay, ${ }^{84,85)}$ recharge from runoff at the Hanford Site, Washington, ${ }^{86)}$ nutrient loading to the Potomac River, ${ }^{87)}$ stream temperature simulation of forested riparian areas, ${ }^{88,89)}$ and hourly stream temperature and daily dissolved solids for the Truckee River, California and Nevada. ${ }^{90)}$

\subsection{SWMM}

The EPA storm water management model (SWMM) is a dynamic rainfall-runoff simulation model used for single event or long-term (continuous) simulation of runoff quantity and quality from primarily urban areas. SWMM was first developed in $1971^{11)}$ and has undergone several major upgrades since then. ${ }^{12,31,91)}$ The runoff component of SWMM operates on a collection of subcatchment areas that receive precipitation and generate runoff and pollutant loads. The routing portion of SWMM transports this runoff through a system of pipes, channels, storage/treatment devices, pumps, and regulators. SWMM tracks the quantity and quality of runoff generated within each sub-catchment, and the flow rate, flow depth, and quality of water in each pipe and channel during a simulation period comprised of multiple time steps.

SWMM estimates the production of pollutant loads associated with runoff considering the following:

- dry-weather pollutant buildup over different land uses

- pollutant wash-off from specific land uses during storm events

- direct contribution of rainfall pollutant deposition

- reduction in dry-weather pollutant buildup due to street cleaning

- reduction in pollutant wash-off load due to BMPs

- entry of dry weather sanitary flows and user-specified external inflows at any point in the drainage system

- routing of water quality constituents/pollutants through the drainage system

- reduction in pollutant concentrations by treatment in storage units or natural processes in pipes and channels

The current edition, version $5,{ }^{31)}$ is a complete re-write of the previous release. Running under Windows, SWMM 5 provides an integrated environment for editing study area input data, running hydrologic, hydraulic and water quality simulations, and viewing the results in a variety of formats. These include color-coded drainage area and conveyance system maps, time series graphs and tables, profile plots, and statistical frequency analyses.

\subsection{SWAT}

The USDA soil and water assessment tool (SWAT) is a physically based, spatially distributed, watershed scale model. ${ }^{92-97)}$ The model was developed to predict impacts of land management practices on water, sediment, and agricultural chemical yields in large, complex watersheds. SWAT considers land use and soils data, and calculates the spatial overlap between soil types and land use types. Each unique land use-soil type combination is treated as a separate hydrologic response unit (HRU), with its own set of governing parameters. The areal sum of the output from each HRU within a sub-basin becomes the total output from that sub-basin, whether water, sediment, nutrients, or some other pollutant.

SWAT reads daily precipitation files, and uses either the SCS curve number method or the Green-Ampt method to calculate runoff volume and infiltration. Plant growth and evapotranspirative extraction of water from the root zone are simulated. Overland flow and subsurface flow are simulated with a kinematic wave approach. Erosion is computed using the modified universal soil loss equation, MUSLE. Multiple soil layers are simulated, including the root zone, with downward soil water movement between layers and lateral discharge into channels. When soil water content exceeds the field capacity, downward movement between layers and discharge of excess water into streams occurs in a first-order fashion subject to a lateral flow lag with a calculated travel time coefficient. The presence of drain tiles can be accounted for through the lag time coefficient, or subsurface travel time to the stream can be computed as a function of hill-slope and hydraulic conductivity. Aquifer recharge from soil water is treated as a first-order function of time. Variable groundwater depth is simulated, and recharge to streams is treated as a function of groundwater depth, subject to a userdefined recession coefficient. Besides the water table aquifer, loss to deep groundwater is also simulated, as in HSPF. Overland flow and channel flow are both simulated with Manning's equation. Constituent/pollutant transport to streams from the surface via subsurface flow is explicitly simulated in the same first-order manner as the soil water discharge to streams.

The nitrogen cycle is simulated using 5 different $\mathrm{N}$ pools, NH3, $\mathrm{NO} 3$, and 3 different kinds of organic $\mathrm{N}$ (plant residues and active and labile humics). Nitrification, denitrification, and $\mathrm{N}$ fixation and mineralization are all simulated. Denitrification is treated as a function of soil carbon when soil moisture exceeds a specified threshold. Mineral and organic forms of P, and transformations between them, are also simulated. For pesticides and fertilizers, various management practices can be simulated; e.g., different timing of and application rates, and tillage operations.

\subsection{EFDC}

The environmental fluid dynamics code (EFDC) hydro is an orthogonal, curvilinear grid hydrodynamic model that can be used to simulate aquatic systems in one, two, and three dimensions. ${ }^{29)}$ EFDC can solve the circulation and transport of material in complex surface water environments including estuaries, coastal embayments, lakes, and offshore. EFDC uses stretched or sigma vertical coordinates and Cartesian or curvilinear, orthogonal horizontal coordinates to represent the physical characteristics of a water body. It solves three-dimensional, vertically hydrostatic, 
free surface, turbulent averaged equations of motion for a variable-density fluid. Dynamically coupled transport equations for turbulent kinetic energy, turbulent length scale, salinity and temperature are also solved. EFDC allows for drying and wetting in shallow areas by a mass conservation scheme. The physics of EFDC and many aspects of the computational scheme are equivalent to the widely used Blumberg-Mellor model, $\mathrm{POM},{ }^{30}$ and U.S. Army Corps of Engineers' Chesapeake Bay model, CH3D ${ }^{27)}$ EFDC produces a special hydrodynamic output file that can be selected for input to WASP. This file includes network segmentation and time-varying flows, velocities, depths, volumes, salinity, and temperature.

\section{References}

1. Streeter, H. W. and Phelps, E. B., A study of the pollution and natural purification of the Ohio River. III. Factors concerned in the phenomena of oxidation and reaeration, Public Health Bulletin No. 146, Public Health Service, Washington, DC (Feb, 1925).

2. Bowie, G. L., Mills, W. B., Porcella, D. B., Campbell, C. L., Pagenkopf, J. R., Rupp, G. L., Johnson, K. M., Chan, P. W. H., Gherini, S. A., and Chamberlin, C. E., Rates, constants, and kinetics formulations in surface water quality modeling, 2nd ed., EPA/600/3-85-040, U.S. Environmental Protection Agency, Athens, GA (1985).

3. Schnoor, J. L., Sato, C., McKetchnie, D., and Sahoo, D., Processes, coefficients, and models for simulating toxic organics and heavy metals in surface waters, EPA/600/387-015, U.S. Environmental Protection Agency, Athens, GA (1987).

4. Di Toro, D. M., O'Connor, D. J., and Thomann, R. V., A dynamic model of the phytoplankton population in the Sacramento San Joaquin Delta, Advances in Chemistry Vol. 106, Ch. 5, American Chemical Society, Washington, DC, pp. 131-180 (1971).

5. Thomann, R. V., Mathematical modeling of phytoplankton in Lake Ontario 1. Model development and verification, EPA/600/3-75-005, U.S. Environmental Protection Agency, Corvallis, OR (1975).

6. Thomann, R. V., Winfield, R. P., Di Toro, D. M., and O'Connor, D. J., Mathematical modeling of phytoplankton in Lake Ontario 2. Simulations using LAKE 1 Model, EPA/600/3-76065, U.S. Environmental Protection Agency, Grosse Ile, MI (1976).

7. Thomann, R. V., Winfield, R. P., and Segna, J. J., Verification analysis of Lake Ontario and Rochester Embayment three dimensional eutrophication models, EPA/600/3-79-094, U.S. Environmental Protection Agency, Grosse Ile, MI (1979).

8. Thomann, R. V., "Mathematical model of dissolved oxygen," $J$. San. Engr. Div. ASCE, 89(SA5), 1-30 (1963).

9. Final progress report - Delaware estuary and bay water quality sampling and mathematical modeling project, Delaware River Basin Commission, Trenton, NJ (May, 1970).

10. Feigner, K. D. and Harris, H. S., Documentation report: FWQA dynamic estuary model, U.S. Federal Water Quality Administration, Washington, DC (1970).
11. Metcalf \& Eddy Inc., University of Florida, and Water Resources Engineers Inc., Storm water management model (SWMM), volume I - final report, 11024DOC07/71, Water Quality Office, U.S. Environmental Protection Agency, Washington, DC (Jul, 1971).

12. Huber, W. C., Heaney, J. P., Medina, M. A., Peltz, W. A., Sheikh, H., and Smith, G. F., Storm water management model (SWMM) user's manual, version II, EPA/670/2-75/017, U.S. EPA Environmental Research Center, Cincinnati, OH (Mar, 1975).

13. Simulation of water quality in streams and canals, program documentation and users manual, Texas Water Development Board, Austin, TX (Sep, 1970).

14. Duke, J. H., Provision for a steady-state version of the stream model QUAL, Water Resources Engineers, Inc., Austin, TX (1973).

15. Roesner, L. A., Gigure, P. A., and Evenson, D. E., Computer program documentation for the stream water quality model QUAL-II, EPA/600/9-81-014, U.S. EPA Environmental Research Laboratory, Athens, GA (1981).

16. Najarian, T. O. and Harleman, D. R. F., Real-time model of nitrogen-cycle dynamics in an estuarine system, Technical Report No. 204, R.M. Parsons Laboratory for Water Resources and Hydrodynamics, Dept. of Civil Engineering, Massachusetts Institute of Technology, Cambridge, MA (Jul, 1975).

17. Crawford, N. H. and Linsley, R. K., Digital simulation in hydrology, Stanford watershed model IV, Technical report no. 39, Department of Civil Engineering, Stanford University, Stanford, CA (Jul, 1966).

18. Johanson, R. C., Imhoff, J. C., Kittle, J. L., and Donigian, A. S., Jr., Hydrological simulation program - FORTRAN (HSPF): user's manual for release 8.0, EPA/600/3-84-066, U.S. EPA Environmental Research Laboratory, Athens, GA (1984).

19. Di Toro, D. M., Fitzpatrick, J. J., and Thomann, R. V., Water quality analysis simulation program (WASP) and model verification program (MVP) - Documentation, EPA/600/3-81044, U.S. EPA Environmental Research Laboratory, Duluth, MN (1983).

20. Ambrose, R. B., Vandergrift, S. B., and Wool, T. A., WASP3, a hydrodynamic and water quality model-model theory, users manual, and programmers guide, EPA/600/3-86/034, U.S. Environmental Protection Agency, Athens, GA (1986).

21. Brown, L. C. and Barnwell, T. O., Computer program documentation for the enhanced stream water quality model QUAL2E, EPA/600/3-85/065, U.S. EPA Environmental Research Laboratory, Athens, GA (Aug, 1985).

22. Burns, L. A., Cline, D. M., and Lassiter, R. R., Exposure analysis modeling system (EXAMS): user manual and system documentation, EPA/600/3-82-023, U.S. Environmental Protection Agency, Athens, GA (1982).

23. Burns, L. A. and Cline, D. M., Exposure analysis modeling system, reference manual for EXAMS II, EPA/600/3-85-038, U.S. Environmental Protection Agency, Athens, GA (1985).

24. Ambrose, R. B., Wool, T. A., Connolly, J. P., and Schanz, R. W., WASP4, a hydrodynamic and water quality model-model theory, users manual, and programmers guide, EPA/600/3- 
87/039, U.S. Environmental Protection Agency, Athens, GA (1987).

25. Brown, L. C. and Barnwell, T. O., Computer program documentation for the enhanced stream water quality model QUAL2E and QUAL2E-UNCAS, EPA/600/3-87/007, U.S. EPA Environmental Research Laboratory, Athens, GA (Aug, 1987).

26. Barnwell, T. O., Brown, L. C., and Whittemore, R. C., "Importance of field data in stream water quality modeling using QUAL2E-UNCAS,” J. Environ. Eng., 130(6), 643-647 (2004).

27. Chapman, R. S., Johnson, B. H., and Vemulakonda, S. R., User's guide for the sigma stretched version of CH3DWES-a three-dimensional numerical hydrodynamic, salinity, and temperature model, HL-TR-96-2, U.S. Army Corps of Engineers, Waterways Experiment Station, Vicksburg, MS (1996).

28. Cerco, C. F. and Cole, T., "Three-dimensional eutrophication model of Chesapeake Bay," J. Environ. Eng., 119(6), 1006-1025 (1993).

29. Hamrick, J. M., Users manual for the environmental fluid dynamics computer code, Special report in applied marine science and ocean engineering Vol. 331, Virginia Institute of Marine Science, College of William and Mary, Williamsburg, VA (1996).

30. Blumberg, A. F. and Mellor, G. L., A description of a threedimensional coastal ocean circulation model, In: Heaps, N. S. (Ed.), Three dimensional coastal ocean models, American Geophysical Union, Washington, DC, pp. 1-16 (reprinted) (1987).

31. Rossman, L. A., Storm water management model (SWMM) user's manual version 5.0, EPA/600/R-05/040, National Risk Management Research Laboratory, U.S. EPA Office of Research and Development, Cincinnati, OH http://www.epa. gov/ednnrmrl/models/swmm/epaswmm5_user_manual.pdf (Jul, 2009).

32. Chapra, S. C., Pelletier, G. J., and Tao, H., QUAL2K: a modeling framework for simulating river and stream water quality, version 2.11: documentation and users manual, Department of Civil and Environmental Engineering, Tufts University, Medford, MA (2008).

33. Wool, T. A., Davie, S. R., and Rodriguez, H. N., "Development of three-dimensional hydrodynamic and water quality models to support total maximum daily load decision process for the Neuse River Estuary, North Carolina," J. Water Resour. Plan. Manage.-ASCE, 129(4), 295-306 (2003).

34. Seo, D. and Yu, H., "Error analysis of a steady state water quality model, QUAL2E using a combination of EFDC-hydro and WASP7.2," IWA World Water Congress and Exhibition, Vienna, Austria (2008).

35. Seo, D., Kwon, K., Park, B., and Sigdel, R., "Water quality modeling Yongdam Lake using EFDC 3-D hydrodynamics model and WASP7.3 water quality model," World City Water Forum (WCWF), Incheon, Korea (2009).

36. Seo, D., Sigdel, R., Kwon, K., Lee, Y., and Yum, K., “3-D hydrodynamic modeling of Yongdam Lake, Korea using EFDC," 13th International Water Association Conference on Integrated Diffuse Pollution Management (IWA DIPCON
2009), Seoul, Korea (2009).

37. National Research Council (US). Committee on Models in the Regulatory Decision Process., Models in environmental regulatory decision making, National Academies Press, Washington, D.C. (2007).

38. Guidance on the development, evaluation, and application of environmental models, EPA/100/K-09/003, Council for Regulatory Environmental Modeling, U.S. Environmental Protection Agency, Washington, DC http://www.epa.gov/ crem/library/cred_guidance_0309.pdf (Mar, 2009).

39. Park, R. A., Clough, J. S., and Wellman, M. C., AQUATOX (Release 2) modeling environmental fate and ecological effects in aquatic ecosystems. Volume 1: user's manual, EPA823-R-04-001, Office of Water, U.S. Environmental Protection Agency, Washington, DC http://www.epa.gov/waterscience/ models/aquatox/users/user.pdf (Jan, 2004).

40. Wool, T. A., Ambrose, R. B., Martin, J. L., and Comer, E. A., The water quality analysis simulation program, WASP6. Part A: Model documentation, U.S. Environmental Protection Agency, Center for Exposure Assessment Modeling, Athens, GA (2001).

41. Ambrose, R. B., Hill, S. I., and Mulkey, L. A., User's manual for toxic chemical transport and fate model (TOXIWASP), EPA/600/3-83/005, U.S. Environmental Protection Agency, Athens, GA (1983).

42. Thomann, R. V. and Fitzpatrick, J. J., Calibration and verification of a mathematical model of the eutrophication of the Potomac Estuary, Department of Environmental Services, Government of the District of Columbia, Washington, DC (1982).

43. Ambrose, R. B., Martin, J. L., and Wool, T. A., WASP7 Benthic algae - model theory and user's guide, EPA/600/R-06/106, U.S. Environmental Protection Agency, Washington, DC (2006).

44. Ambrose, R. B. and Wool, T. A., WASP7 Stream transport model theory and user's guide, supplement to water quality analysis simulation program (WASP) user documentation, EPA/600/R-09/100, U.S. Environmental Protection Agency, Washington, DC (2009).

45. Di Toro, D. M. and Connolly, J. P., Mathematical models of water quality in large lakes, Part 2: Lake Erie, EPA 600/3-80065, U.S. EPA Environmental Research Laboratory, Athens, GA (1980).

46. O'Connor, D. J., Mueller, J. A., and Farley, K. J., "Distribution o Kepone in the James River estuary," J. Environ. Eng., 109(2), 396-413 (1983).

47. Development of heavy metal waste load allocations for the Deep River, North Carolina, JRB Associates, Inc., McLean, VA (1984).

48. Ambrose, R. B., "Modeling volatile organics in the delaware estuary,” J. Environ. Eng., 113(4), 703-721 (1987).

49. Lung, W. S., Martin, J. L., and McCutcheon, S. C., "Eutrophication analysis of embayments in Prince William Sound, Alaska," J. Environ. Eng., 119(5), 811-824 (1993).

50. Bierman, V. J., Hinz, S. C., Zhu, D. W., Wiseman, W. J., Rabalais, N. N., and Turner, R. E., "A preliminary mass-balance model of primary productivity and dissolved-oxygen in the 
Mississippi River plume inner gulf shelf region," Estuaries, 17(4), 886-899 (1994).

51. Lung, W. S. and Larson, C. E., "Water-quality modeling of upper Mississippi River and lake Pepin,” J. Environ. Eng., 121(10), 691-699 (1995).

52. Gualtieri, C. and Rotondo, G., "Water quality modeling of Speed River. Part one: Model calibration (in Italian)," Ingegneria Sanitaria, (2) (1996).

53. Gualtieri, C. and Rotondo, G., "Water quality modeling of Speed River. Part two: Model validation and application (in Italian)," Ingegneria Sanitaria, (5/6) (1996).

54. Wang, P. F., Mill, T., Martin, J. L., and Wool, T. A., "Fate and transport of metam spill in Sacramento River," J. Environ. Eng., 123(7), 704-712 (1997).

55. Pickett, P. J., "Pollutant loading capacity for the Black River, Chehalis River system, Washington," J. Am. Water Resour. Asssoc., 33(2), 465-480 (1997).

56. Tsiros, I. X. and Ambrose, R. B., "Environmental screening modeling of mercury in the upper everglades of South Florida," J. Environ. Sci. Health Part A-Toxic/Hazard. Subst. Environ. Eng., 33(4), 497-525 (1998).

57. Tsiros, I. X. and Ambrose, R. B., "An environmental simulation model for transport and fate of mercury in small rural catchments," Chemosphere, 39(3), 477-492 (1999).

58. Tufford, D. L. and McKellar, H. N., "Spatial and temporal hydrodynamic and water quality modeling analysis of a large reservoir on the South Carolina (USA) coastal plain," Ecol. Model., 114(2-3), 137-173 (1999).

59. Tufford, D. L., McKellar, H. N., Flora, J. R. V., and Meadows, M. E., "A reservoir model for use in regional water resources management," Lake Reserv. Manage., 15(3), 220 - 230 (1999).

60. Wang, P. F., Martin, J., and Morrison, G., "Water quality and eutrophication in Tampa Bay, Florida," Estuar. Coast. Shelf Sci., 49(1), 1-20 (1999).

61. Caruso, B. S., "Water quality simulation for planning restoration of a mined watershed," Water Air Soil Pollut., 150(1-4), 359-382 (2003).

62. Caruso, B. S., "Modeling metals transport and sediment/ water interactions in a mining impacted mountain stream," $J$. Am. Water Resour. Assoc., 40(6), 1603-1615 (2004).

63. Caruso, B. S., "Simulation of metals total maximum daily loads and remediation in a mining-impacted stream," $J$. Environ. Eng., 131(5), 777-789 (2005).

64. Ambrose, R. B., Tsiros, I. X., and Wool, T. A., "Modeling mercury fluxes and concentrations in a Georgia watershed receiving atmospheric deposition load from direct and indirect sources," J. Air Waste Manage. Assoc., 55(5), 547-558 (2005).

65. A review of the mathematical water quality model QUALII and guidance for its use, Technical Bulletin No. 0391, National Council of the Paper Industry for Air and Stream Improvement (NCPIASI), New York, NY (Dec, 1982).

66. A study of the selection, calibration and verification of mathematical water quality model, Technical Bulletin No. 0367, National Council of the Paper Industry for Air and
Stream Improvement (NCAPISI), New York, NY (Dec, 1982).

67. McCutcheon, S. C., Evaluation of selected one-dimensional water quality models with field data, Technical Report E-8311, U.S. Army Waterways Experiment Station, Vicksburg, MS (1983).

68. Modifications to the QUAL-2 water quality model and user manual for QUAL2E version 2.2, Technical Bulletin No. 0457, National Council of the Paper Industry for Air and Stream Improvement (NCPIASI), New York, NY (Apr, 1985).

69. Chapra, S. C., QUAL2K: a modeling framework for simulating river and stream water quality (beta version): documentation and users manual, Department of Civil and Environmental Engineering, Tufts University, Medford, MA (2003).

70. Chapra, S. C. and Pelletier, G. J., QUAL2K: a modeling framework for simulating river and stream water quality, version 1.3: documentation and users manual, Department of Civil and Environmental Engineering, Tufts University, Medford, MA (2004).

71. Donigian, A. S., Jr., Beyerlein, D. C., Davis, H. H., Jr., and Crawford, N. H., Agricultural runoff management (ARM) model version II: refinement and testing, EPA/600/3-77-098, U.S. EPA Environmental Research Laboratory, Athens, GA (1977).

72. Donigian, A. S., Jr. and Davis, H. H., Jr., User's manual for agricultural runoff management (ARM) model, EPA/600/378-080, NTIS/PB-286-366/OWP, U.S. EPA Environmental Research Laboratory, Athens, GA (1978).

73. Donigian, A. S., Jr. and Crawford, N. H., User's manual for the nonpoint source (NPS) model, NTIS/PB-270-967/3WP, U.S. EPA Environmental Research Laboratory, Athens, GA (1979).

74. Johanson, R. C., Imhoff, J. C., Davis, H. H., Kittle, J. L., and Donigian, A. S., Jr., User's manual for the hydrological simulation program - FORTRAN (HSPF), version no. 7.0, U.S. EPA Environmental Research Laboratory, Athens, GA (1981).

75. Donigian, A. S., Jr., Imhoff, J. C., Bicknell, B. R., and J.L. Kittle, J., Application guide for the hydrologic simulation program FORTRAN (HSPF): users manual for release 8.0, EPA/600/384-066, U.S. EPA Environmental Research Laboratory, Athens, GA (1984).

76. Bicknell, B. R., Imhoff, J. C., Kittle, J. L., Jr., Donigian, A. S., Jr. , and Johanson, R. C., Hydrological simulation program FORTRAN. User's manual for release 10, EPA/600/R-93-174, U.S. EPA Environmental Research Laboratory, Athens, GA (1993).

77. Bicknell, B. R., Imhoff, J. C., Kittle, J. L., Jr., Donigian, A. S., Jr. , and Johanson, R. C., Hydrological simulation program FORTRAN. User's manual for version 11, U.S. EPA National Exposure Research Laboratory, Athens, GA (1997).

78. Bicknell, B. R., Imhoff, J. C., Kittle, J. L., Jr., Jobes, T. H., and Donigian, A. S., Jr., Hydrological simulation program - Fortran (HSPF). User's manual for release 12, U.S. EPA National Exposure Research Laboratory, Athens, GA (2001).

79. Donigian, A. S., Jr., Imhoff, J. C., and Bicknell, B. R., Modeling water quality and the effects of best management practices in Four Mile Creek, Iowa, EPA/68-03-2895, U.S. EPA Environmental Research Laboratory, Athens, GA (1983). 
80. Imhoff, J. C., Bicknell, B. R., and Donigian, A. S., Jr., Preliminary application of HSPF to the Iowa River Basin to model water quality and the effects of agricultural best management practices, Contract No. 68-03-2895 (PB83-250399), Office of Research and Development, U.S. Environmental Protection Agency (1983).

81. Bicknell, B. R., Donigian, A. S., and Barnwell, T. A., "Modeling water-quality and the effects of agricultural best management-practices in the Iowa River Basin," Water Sci. Technol., 17(6-7), 1141-1153 (1985).

82. Chew, C. Y., Moore, L. W., and Smith, R. H., "Hydrological simulation of Tennessee's north Reelfoot Creek watershed," Res. J. Water Pollut. Contr. Fed., 63(1), 10-16 (1990).

83. Dinicola, R. S., Characterization and simulation of rainfallrunoff relations for headwater basins in Western King and Snohomish Counties, Washington, Water Resources Investigation Report 89-4052, U.S. Geological Survey, Tacoma, WA (1990).

84. Donigian, A. S., Jr., Bicknell, B. R., Patwardhan, A. S., Linker, L. C., Chang, C. H., and Reynolds, R., Chesapeake Bay program - Watershed model application to calculate bay nutrient loadings: final findings and recommendations (final report), U.S. EPA Chesapeake Bay Program, Annapolis, MD (1994).

85. Linker, L. C., Shenk, G. W., Wang, P., and Storrick, J. M., Chesapeake Bay watershed model application and calculation of nutrient and sediment loadings. Appendix B. Phase 4 Chesapeake Bay watershed model water quality calibration results, EPA/903/R-98/003, U.S. Environmental Protection Agency, Chesapeake Bay Program, Annapolis, MD (1998).

86. Dinicola, R. S., Estimates of recharge from runoff at the Hanford Site, Washington, Water Resources Investigation Report 97-4038, U.S. Geological Survey, Tacoma, WA (1997).

87. Stigall, E., Linker, L. C., and A.S. Donigian, J., "Application of the hydrologic simulation program-FORTRAN (HSPF) model to the Potomac River Basin," Proc. WATERSHED '93: A National Conference on Watershed Management, Alexandria, VA, pp. 767-775 (Mar 21-24, 1993).

88. Chen, Y. D., Carsel, R. F., McCutcheon, S. C., and Nutter, W. L., "Stream temperature simulation of forested riparian areas: I. Watershed-scale model development," J. Environ. Eng., 124(4), 304-315 (1998).

89. Chen, Y. D., McCutcheon, S. C., Norton, D. J., and Nutter, W. L., "Stream temperature simulation of forested riparian areas: II. Model application," J. Environ. Eng., 124(4), 316-328 (1998).

90. Taylor, R. L., Simulation of hourly stream temperature and daily dissolved solids for the truckee river, California and Nevada, Water Resources Investigation Report 98-4064, U.S. Geological Survey, Carson City, NV (1998).

91. Huber, W. C. and Dickinson, R. E., Storm water management model (SWMM), version 4: user's manual, EPA/600/388/001a, U.S. EPA Environmental Research Laboratory, Athens, GA (Oct, 1992).

92. Srinivasan, R. and Arnold, J. G., "Integration of a basin-scale water-quality model with GIS” Water Resour. Bull., 30(3), 453462 (1994).

93. Arnold, J. G., Williams, J. R., and Maidment, D. R.,
"Continuous-time water and sediment routing model for large basins" J. Hydraul. Eng.-ASCE, 121 (2), 171-183 (1995). 94. Arnold, J. G., Srinivasan, R., Muttiah, R. S., and Williams, J. R., "Large area hydrologic modeling and assessment - Part 1: Model development," J. Am. Water Resour. Asssoc., 34(1), 7389 (1998).

95. Srinivasan, R., Ramanarayanan, T. S., Arnold, J. G., and Bednarz, S. T., "Large area hydrologic modeling and assessment - Part II: Model application," J. Am. Water Resour. Asssoc., 34(1), 91-101 (1998).

96. Neitsch, S. L., Arnold, J. G., Kiniry, J. R., Williams, J. R., and King, K. W., Soil and water assessment tool. Theoretical documentation version 2000, TWRI Report TR-191, Texas Water Resources Institute, College Station, TX ftp:/ ftp.brc. tamus.edu/pub/swat/doc/swat2000theory.pdf (2002).

97. Neitsch, S. L., Arnold, J. G., Kiniry, J. R., and Williams, J. R., Soil and water assessment tool. Theoretical documentation version 2005, Grassland, Soil And Water Research Laboratory, Agricultural Research Service, Temple, TX http://www.brc. tamus.edu/swat/downloads/doc/swat2005/SWAT\%20 2005\%20theory\%20final.pdf (Jan, 2005). 